\title{
Comparison of Indonesian and Malaysian character education
}

\author{
Marzam $^{1 *}$, Depi Elpina ${ }^{2}$, Rusdinal ${ }^{3}$, Azwar Ananda ${ }^{4}$, Nurhizrah Gistituati ${ }^{5}$ \\ Universitas Negeri Padang, Indonesia ${ }^{1,3,4,5}$ \\ SMPN 2 Padang Pariaman, Indonesia ${ }^{2}$

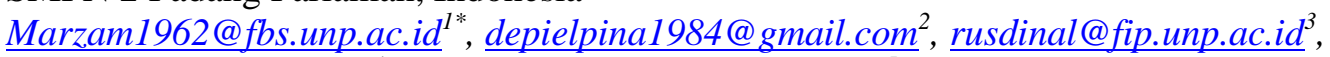 \\ azwar4127@gmail.com ${ }^{4}$, gistituatinurhizrah@gmail.com ${ }^{5}$
}

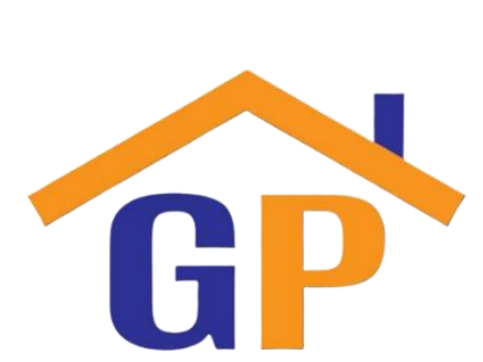

Article History

Received on 22 May 2021

$1^{\text {st }}$ Revision on 22 June 2021

$2^{\text {nd }}$ Revision on 5 July 2021

Accepted on 1 December 2021

\begin{abstract}
Purpose: This study aims to determine the comparison of policies between Indonesia and Malaysia. his comparison is needed to develop Indonesian education policies so that the quality of Indonesian education policies in the future will be better.
\end{abstract}

Research methodology: The research method uses a literature study because it compares education policies. Especially character education between Indonesia and Malaysia.

Results: The results showed that Indonesia's education policies were still categorized as low because it was based on the four components being compared, namely character education goals, character education strategies, education structures, and education management.

Limitations: This study focuses on four components of education policy, particularly character education. There are other parts that can be discussed by further research, namely other parts of Education policy, and can also be compared with other countries.

Contribution: This research can be a consideration for Indonesian policyholders, especially the aspect of character education because it can improve the quality of Indonesian education.

Keywords: Character Education, Education Policy, Indonesia, Malaysia

How to cite: Marzam, M., Elpina, D., Rusdinal, R., Ananda, A., Gistituati, N. (2022). Comparison of Indonesian and Malaysian character education. Journal of Social, Humanity, and Education, 2(1), 115-128.

\section{Introduction}

Education is a process of cultural transfiguration leading to changes in the culture of society and the nation. Therefore, education should be provided with guidance, teaching, and training to be able to develop students' abilities optimally, intellectually, spiritually, socially, morally, and with a mature personality. The efforts mentioned above can form the main process of education in order to guarantee the life of the next community. To develop intellectual function, a selection is made based on intellectual, social, emotional, and motoric physical aspects (Sukmadinata, 2006).

According to Langgulung (1992), education is a process of transferring knowledge. From here we can recognize that education can provide knowledge. The aspects of providing knowledge are as follows:

1) Giving knowledge in the form of teaching. The education that a person can have then is given to others who do not know it.

2) The educational process is part of the training so that they get used to getting competence in a job.

3) Education is the process of imitating a teacher to students. The imitations meant are the ones who decipher the order.

The results of this knowledge can provide changes in the form of planting the values of truth and goodness in humans. This can be seen in the changes in students' behavior according to cultural 
transfiguration from generation to generation of students so that new cultures can be developed according to the character of society to predict changes, for example, informal education in the family, society, and formal education in schools is directly proportional to the roles and functions of education

Education in the family is the main key in developing children's interests and talents, especially developing behavior and self-competence. Formal education in schools can increase children's academic knowledge, behavior, and self-competence which can contribute to the cultural structure. Forming a young generation can improve intelligence intellectually and socially. Thus, it can provide solutions to the problems at hand. Formal education in schools and informal education in the family should be able to strengthen the relationship between the two of them for students. This has an impact on the values of modern culture, politics, socio-culture, economics, and technology derived from the curriculum materials of Plato and Aristotle (Soedijarto, 2000).

Giving educational knowledge in schools can give birth to educational programs that require a foundation in other branches of science. This knowledge takes the form of scientific studies on (1) the spiritual relationship between students and teachers; (2) social phenomena in the form of socialization activities from young people to older generations can be said as international relations; (3) norm is a symbolic transaction. The content of education includes ideas, real objects, bodies, social phenomena in humans and the environment (Uno, 2006).

Education is a cultural phenomenon that affects the social environment. Thus, education is dynamic so that changes can be carried out continuously. The effort needed for this change is to formulate culture intensively and the novelty of cultural education for the community. Education can promote human and cultural change and lead to change or innovation in education.

In the context of change that can reflect educational innovation, there are a number of important issues that need to be known, namely

1) Change is something that cannot be avoided

2) The experience of change is always boring

3) Change can be equated with the progress that is difficult to understand

4) Change is not instantaneous but takes time

5) The obstacle faced towards change is a political process

6) Togetherness process is needed to be able to replace the political process

7) Difficulty in implementing progress is a matter of nationality

Changes in education can be put forward based on aspects (1) a paradigm shift from teaching to learning; (2) changes from the multi-intelligence of children; (3) student learning center; (4) deductive teaching pattern becomes inductive. In line with technological developments, there are a number of competencies that teachers and principals must possess. There are three main challenges in the world of education in Indonesia, as follows: first, the world of education must be able to protect the results of development; second, to provide competent resources capable of facing competition in the global job market; third, it is necessary to change and adapt to the national education system to create a democratic education process and increase public participation (Uno, 2006).

Based on the three main challenges above, it is necessary to reorganize the education policy to improve intelligence and the quality of human resources. (1) implementation of school-based management (2) curriculum policy at the educational unit level; (3) and the application of character education. This research focuses on the application of character education. This aims to determine the application of character education can improve the quality and quality of human resources.

\section{Literature review and hypothesis development}

In this subpoint, it discusses the theory and research that is relevant to the research in this study. The first thing to explain is the theory related to this research is change or innovation in education. According to KBBI (2014), innovation can be interpreted as replacing old ways with new ways. Innovators are carriers of new ways. According to Drucker (1990) argues that innovation is a change to 
give birth to a new dimension of performance. According to Rogers and Shoemaker (1987), innovation is an idea, action, or item that is considered new or unmeasurable. by time. Thus it can be said that innovation can be developed by organizations or humans based on the urge to find solutions, human creativity can create progress. Early things can be realized through ideas, ideas, actions created by humans from their creativity so as to bring benefits and cultural progress.

This innovation should bring about a large number of developments (Wijaya, 1992). Development can be categorized as research and development $(\mathrm{R}$ and $\mathrm{D})$ which is commonly done in education. $\mathrm{R}$ and $\mathrm{D}$ can be used in various activities, namely basic research such as searching and testing learning theories. In line with this innovation and development, there are emergencies accompanied by the spread of new ideas in renewal. This distribution is a planned pattern, with steps that have a target (Wijaya, 1992).

According to King and Anderson (1995), they describe the characteristics of innovation including (1) can be silenced, the process of producing an innovation that can be felt; (2) innovation must have a background which a working group can know; (3) innovation aims permanently; (4) innovation is not a routine change.

There are five types of innovation according to the opinion of the hali, namely

1. Product innovation in the form of introducing new goods, new services that can be used, such as cellphones, computers, and motor vehicles

2. Process innovation applying quality to new products

3. Marketing innovation to develop market methods to improve the quality of design, packaging, and promotion.

4. Organizational innovation in the form of organizational behavior

Business model innovation is in the form of a business pattern with adopted values. Amabile (1992) states that the driving factor for innovation is leadership. In addition, organizational structure and process factors can work together in organizations, organizational learning abilities (Tsai, 2001). Other factors that have an impact on innovation are the conducive working and creative environment Amabile (1992) the complexity of workers and the type of supervision within the company (Oldham and Cumming, 1996), and the culture of the organizational climate (Mumford and Gustafson, 1996), as well as a great planner in the application of organizational activities (Collin, 2002).

Based on the explanation above, several important terms can be taken related to educational innovation, namely

a. New words correlate with things that other people don't already know.

b. The word qualitative relates to rearrangements in education in the form of types and groupings of lessons, time, classrooms, learning strategies through labor, tools, money. This is done to achieve quality in innovation action.

c. Words include the education system in the form of ideas and ideas that are realized by methods, techniques, regulations, norms, goods, and tools.

d. The word deliberately is in the form of educators\&\#39; expectations about the learning process

e. Capability improvement means that capabilities come from manpower, money, and facilities, categorized as organizational structures and procedures.

f. Goals can produce targets that have been previously achieved, measured, and implemented.

Next, Rogers (1987) states that the characteristics of innovation include:

a. Excellence in ideas and ideas using parameters of economic, social, satisfaction, and comfort factors

b. Conformity refers to innovation in values, experiences, and needs

c. Complexity is related to the level of difficulty of innovation in balance with its function

d. Trialability relates to the level of trial and error of an innovation

e. Observability refers to the usefulness of innovation to society 
The results of Rogers' statement create originality, creativity, and modernity. The application of these three elements can lead to comfort and convenience. In addition, there are benefits of educational innovation as an effort to improve the quality of education to get quality / superior education. The literature review is taken from a number of journals relevant to this research on the curriculum which discusses the objectives, content/material, media, strategies, and teaching and learning processes.

First, Istianingsih (2016) discusses the character education of the most developed countries in ASEAN. Isnianingsih's research aims to find the pillars of character education. Her research results show that among ASEAN countries, Singapore is superior in terms of economic, social, educational, and technological aspects. The character education of the people of Singapore is obtained from the results of his education. There are ten kinds of dominant character in Singapore society, namely (1) able to build human character; (2) able to build a creative human being; (3) able to develop people who have a work ethic; (4) able to build complete work; (5) able to develop motivated people; (6) able to develop disciplined human beings; (7) able to develop people who can look for opportunities; (8) able to develop collaborative people; (9) able to develop people who respect the work ethic; and (10) able to develop people who think objectively.

Second, Thambusamy and Elier, (2013) in Shaping the Bamboo from the Shoot: Elementary Level Character Education in Malaysia. This article focuses on the introduction of giving character education to child development in order to raise moral citizens. This research describes the history of character education as moral education in Malaysia. Suggestions in this research are that the syllabus of basic character education in Malaysia has just been revised. The syllabus in question contains the value of balance to improve eels and certain virtuous habits, build moral judgments and think logically about justice. The results showed that the development of the community formed bamboo plants. Bamboo is a very useful plant for East and Southeast Asian people, such as living quarters, furniture, cutlery, and cooking. To be able to produce healthy and productive moral people the process begins with instilling moral education in the basic Malaysian curriculum.

Third, Saidek, Islami, Abduludin, (2016) analyzed in Character Issues: Reality Character Problems and Solutions through Education in Indonesia. The results of their research contain to concern about the problems of character education, namely corruption, student fights, drug sex, and rape/abortion can be resolved properly. An alternative step used to solve character education problems is to reconnect the relationships and networks of the three educational institutions. The results of their research show that character education can build Pancasila values, namely being faithful and pious, honest and clean, polite and intelligent, responsible and working hard, disciplined and creative, caring and loving help. All these values of Pancasila should be in synergy with every subject in Indonesia. The strategy that is carried out to simplify the characterization of this character requires the role of the government through character education, practitioner experience strategies. This improvement can also be done with a central experience strategy that is integrated into co-curriculum and extracurricular activities.

Fourth, Hanh, Loan, and Viet, (2020) discussed in Quality Framework of Higher Education in Vietnam, Malaysia, and Nigeria. Their research objective was to identify Vietnamese, Malaysian, and Nigerian quality assurance institutions operating to ensure quality in higher education institutions. $\mathrm{n}$ addition, this study provides an appreciation for the quality assurance and framework of higher education institutions. Quality assurance systems are concerned with social issues based on key concepts, such as autonomy, accountability, and enhancement. The method used is the method of qualitative document analysis and higher education and relevant policies, the education quality assurance system, and training of the Ministry of Vietnam, the quality agency of the National University Commission, the National Council for Technical Education of Nigeria, and the Malaysian Qualifications Agency. Vietnam and Malaysia have a single quality assurance system while Nigeria has a dual guarantee system. In all three quality assurance systems, the country made achievements in terms of autonomy, accountability, and enhancement. In Vietnam, the Vietnam Qualifications Agency: Internal Quality Assurance is embedded in the accreditation system but still requires external quality assurance agency recognition. In Malaysia, the Malaysian Qualifications Board: Internal Quality Assurance is embedded in the accreditation system and reduces the involvement of external Quality Assurance bodies. In Nigeria, the National University 
Commission, the National Council for Technical Education, and the National Commission for Higher Education Colleges in Nigeria provide guidelines for higher education institutions to help build their internal Quality Assurance. Quality Assurance Vietnam and Malaysia experienced demonstrated accountability for continuous improvement while Nigerias' Quality Assurance accountability was seen with improvements not seen due to challenges associated with the quality framework. This study provides a valued vision into the Quality Assurance system and framework of higher education institutions and how Quality Assurance responds to the social demands of stakeholders.

Fifth, Kim, Harris, Pham, (2018) examined How Character Education Impacts Teachers. Their research aims to present that teachers have the belief to increase the effectiveness of character education to fulfill their career development. The research method they used was a quantitative method to answer research questions with 170 respondents and 159 respondents involved in data collection. Analysis using statistical software SPSS. Bivariate correlation looks at the relationship between the independent variable perceptions of the effectiveness of the character education program with the dependent variable teacher career satisfaction. Multiple linear regression is used to see that the level of teacher school teaching is influenced by the predictive relationship between perceptions of the effectiveness of character education programs and career satisfaction. The results showed that the relationship between teachers' perceptions of the effectiveness of character education programs and career satisfaction. The inferential analysis results from the correlation and regression analysis show that teachers' perceptions of the effectiveness of character education programs have a strong and positive relationship to teacher career satisfaction. The results of this study can support efforts to incorporate character education into the school curriculum to improve the teaching outcomes of teachers and students in schools.

Sixth, Milal et al, (2021) reviewed Integrating Character Education in the English Teaching at Islamic Junior High Schools in Indonesia. The purpose of this study is the skills of teachers in providing moral messages and character education in teaching English. The method used is research and development (R\&D) in developing the ELTIS Islamic Life Resource Pack by involving needs analysis, material design and development, expert validation, material revision, trial testing, the second round of material revision, and final product dissemination. Supporting data group discussion (FGD), interviews with 280 total respondents. The results showed that the additional material used by English teachers to provide character education in the context of Islamic schools. The complementary material is called The Islamic Life Pack (ILRP) to instill Islamic moral values in English teaching materials. The ILRP contains Islamic messages to support teachers to develop the good character needed for students in the era of digital technology.

Seventh, Marini, Safitri, Muda, (2018) examined the Managing School Based on Character Building in The Context Building in The Context of Religious School Culture (Case in Indonesia). This study aims to present a model for the formation of religious characters in the culture of religious schools. The method used is a descriptive method and comparative causal method. The causal-comparative method is part of a systematic empirical search research design with a questionnaire. The questionnaire used exogenous variables and students\&\#39; religious character as endogenous variables. Analysis using statistical techniques with the AMOS application can display paths in the form of a complete model, measurement models, structural models with complete model coefficients, measurement models, raw data, path coefficients, $t$ values, modification indices, and expected changes. The results showed an empirical model in developing students' religious character in the context of religious school culture by instilling religious tolerance towards others and living in harmony with other religions.

Eighth, Abdi, (2018) reviewed The Implementation of Character Education in Kalimantan, Indonesia: Multi Site Studies. The purpose of this study is to instill character education for the morale of the nations' children with character models developed by schools. The research method used is descriptive method with observation, interview, and documentation techniques. Data analysis used interactive analysis by Milles and Hubberman. The results showed that the development of character values through coding programs for the Islamic community, preservation of regional arts, independence and responsibility, the spirit of nationalism and nationalism, and tolerance. 
Ninth, Sokip, et al, (2019) discuss Character Building in Islamic Society: A Case Study of Muslim Families in Tulungagung East Java, Indonesia. The purpose of their research is to identify the position, goals, and roles of parents in shaping children's character. The research method used is descriptive qualitative with data triangulation techniques including interviews, participant observation, and documentation. The data analysis technique used the inductive method in combining the flow of thoughts of the opinions of several experts. The results show that the character-building of children requires the role and responsibility of parents in developing their children's character, for example, creative, tolerant, hardworking, responsible, trustworthy, respectful of nature, and compassionate for other humans so that they are able to make joint decisions, be disciplined, courageous, efficient, diligent, skilled, helpful, and consistent

Tenth, Rosmiati et al. (2016) examined The Effectiveness of Learning Model of Basic Education with Character Based at Universitas Muslim Indonesia. Their research aims to determine the effectiveness of the character-based basic education learning model through learning at the Muslim University of Indonesia. The research method used was a development model adapted from Plomps (1997) learning through several steps, such as initial investigation, design, realization. Test, evaluation, and revision, model implementation.

Eleventh, Anggraini and Kusniarti, (2017) examined the Character and Local Wisdom Based Instructional Model of Indonesian Language in Vocational High Schools. Their research aims to form a character-based Indonesian learning model and local wisdom. The research method used qualitative methods with content analysis of local wisdom. Data analysis was adapted from Bogdan and Biklen in Emzir (2010) through several procedures, namely developing a number of analytical questions; collecting more data in the form of model trials; the model is evaluated and revised then retried; discussing metaphorical, analogical, and conceptual aspects related to the development of local wisdom-based learning models; and the results of the trials are needed to compile a draft book of Indonesian literature learning model based on local wisdom so that it can be used by prospective teachers. Their research results indicate that students can identify local wisdom.

Twelveth, Sumintono, et al, (2012) discuss Moral Education in Malaysia: Challenges and Implementation of Character Education in Schools. Their research aims to determine the development of moral education as part of school character education in Malaysia. The method used is a literature review by analyzing a number of articles and journals that are relevant to the context of moral education in Malaysia. Moral education in Malaysia adopted a model from England. Changes in the form of moral education as a form of character education in schools follow a pattern adapted to curriculum changes. The moral education provided focuses on the application of sixteen pure values which are considered to be reflections of moral values adopted by the multicultural Malaysian society.

Thirteenth, Mansikana and Anggraini (2018) examined character education and the quality of Indonesian education. Their research aims to describe teacher behavior and character education capable of improving the quality of education in Indonesia. The method used in their research was a literature study. This literature study is used to answer problems related to the literature in accordance with existing solutions. The literature used is in the form of books, national and international journals, as well as relevant mass media reviews. Education is associated with character-building through principles, strategies, and learning models that can influence the environment. Environmental dominance has a strong influence on character education. Character education efforts are more effective if they are applied with a strict and scientific basis. Character education can improve the quality of education and human resources so that various problems that arise can be handled properly.

Fourteenht, Maunah (2015) discusses the Implementation of Character Education in Forming Students' Holistic Personality. Maunah (2015) research aims to understand the implementation of character education in shaping students' holistic personalities. The research method used is qualitative research with in-depth interview techniques. Then the data were analyzed using the inductive technique with steps, namely data reduction, data presentation, and data verification. The results showed that the character-building of children could be done through two strategies, namely internal school and school 
external. These two strategies are relevant to four pillars, namely the teaching and learning process, school culture formation activities, habituation activities, and extracurricular activities.

Fifteenth, Santika, (2020) examines Character Education in Online Learning. The purpose of this research is to create a generation of people who have noble morals and have an Indonesian personality. The method used is a qualitative descriptive method with data collection techniques in the form of literature studies from various references based on the phenomena observed through character education in online learning. The results showed that through (1) character education can develop patterns of thinking and behaving in accordance with the philosophy of Pancasila; (2) Character strengthening depends on the role of the family, society, and government which are responsible for developing the potential of their citizens; (3) Filtering other cultural values that are not relevant to Indonesian culture; (4) online learning to identify online terms obtained from the internet; (5) the principle of intelligent strategy uses a constructivist learning approach.

Sixteenth, Sulistiyowati, (2013) analyzed Character Education in Indonesian Language Learning. The purpose of this study is to examine the character education contained in Indonesian language learning. The method used is a literature study by analyzing several sources from national or international journals. The results showed that character education in Indonesian language learning is the introduction of values that are implemented in everyday student behavior during the learning process. Character education is formed with the help of language as a language medium that can have a positive impact on a person\&\#39; s character through filtering foreign terms that are in accordance with Indonesian values and culture so that Indonesian people have their own character.

Seventeenth, Yuliana, (2020) reviewed the Importance of National Character in Revitalizing National Resilience. The research objective is to determine the character of the nation in order to revitalize the nations' resilience. The research method used is the method of literature study obtained from a collection of several articles from national journals and international journals. The results showed that there needs to be a restructuring of the nation's character education. This is due to a multi-dimensional crisis originating from crisis-prone infrastructure, nationality, and society, as well as changes in world order caused by globalization, modernization, industrialization, regional autonomy, environmental degradation, moral degradation, and conflict between groups. The meaning of the importance of character education is maximizing the good and positive components of character that can develop individual and national attitudes. Character education studies include two things, namely aesthetics and ethics. Aesthetics refers to things that humans have justified based on their physical appearance. While ethics refers to the appropriateness of behavior against the rules and norms that apply in society. Another value in character education is the philosophy of Pancasila and Bhineka Tunggal Ika which are the inspiration for strengthening the identity of the nations' character education regardless of diversity. Thus character education becomes the joint responsibility of the state, society, and all national components involved.

\section{Research methodology}

The method in this study uses a literature study by comparing the character education between Indonesia and Malaysia. The indicators used as parameters for assessing character education are the objectives of character education, character education strategies, educational structures, and education management. The data collection method relates to character education, which is to compare four indicators in each country. All data was obtained from magazines, newspapers, the internet, journals, documentation books, and libraries. The literature review in question is a comparison of the educational curricula between Indonesia and Finland sourced from magazines, newspapers, the internet, journals, documentation books, and libraries. This comparative study is needed to discuss the indicators studied in Indonesian and Malaysian character education. 


\section{Results and discussions}

Following are the results of a comparative analysis of Indonesian and Malaysian character education based on the understanding of character, the objectives of character education, and the character education learning strategy.

\section{Definition of character and character education}

Character is a quality of a person's personality. Characters have morals that can differentiate a person from other people (KBBI, 2014). Academically, it can mean the basic process of psychology (Lickona, 1992). In other words, a character can mean behaving well towards others. Thus character is able to express one identity as a form of value from truth and goodness. Character education focuses on the personal formation that originates from the pedagogy of Jerman Foster, (1869-1966). The purpose of character building is to create unity between the behavior and attitudes of each person. Character maturity can be measured by personal qualities (Nurainda and Aulia. 2009).

According to Jermal Foster (1869-1966), there are basic characteristics in character education that are applied in the teaching and learning process.

1) Actions that are used as parameter values are considered as normative guidelines.

2) Coherence can create courage and self-confidence that will not tarnish one's personality.

3) Autonomy where other parties cannot join the campus in personal matters or personal decisions Loyalty is part of the award chosen (Nurainda and Aulia. 2009)

\section{Character education objectives}

(Asmami. 2011) states that the purpose of character education has a value from within students and renewal to respect individual freedom. This character education is one of the government policies, namely

1) Forming a human being with moral

2) Forming an intelligent human being

3) Forming a creative and innovative human being

4) Forming an optimistic and confident human being

5) Forming a human being with a big heart (Aunillah. 2011)

Character education is used to improve the quality of education results which refers to the formation of moral character, relevant to the competence of graduates. Through character education, students should be able to improve their abilities to be applied in daily behavior. Character education can increase emotional intelligence in order to guarantee the future by facing all the challenges faced. This is reinforced by the results of research by Daniel Goleman which states that the success of a person in society is influenced by emotional intelligence as much as $80 \%$ and $20 \%$ is influenced by brain intelligence.

The functions of character education are

a. Developing the basic potential of students in order to have a good personality and behavior

b. Building multicultural community behavior

c. Increasing the civilization of a nation that is competitive in the worlds' interactions (Aunillah. $\underline{2011)}$

\section{Character education learning strategies}

Character education focuses on forming students'; personal attitudes. There are several learning strategies, namely

1. Consideration model: this model was developed by Mc Paul. Paul argues that modeling is different from cognitive development. This consideration model is applied by the teacher through the following stages.

a. The conflict faced by students if they were in that situation.

b. Give orders to students to analyze problems in order to feel the interests of others

c. Responding to responses to problems faced so that students can understand their own feelings before responding to the feelings of others 
d. Classifying student responses to others

e. Formulating the cause and effect of actions that have been taken, such as students needing to respect differences of opinion with others through different perspectives

f. Encourage students to think from various perspectives in order to increase the knowledge they have

g. Encourage students to think critically by considering informed choices and decisions.

2. Cognitive Development Model

This model was developed by Lawrence Kohberg who adapted the thoughts of Jhon Dewey and Jean Piaget, stating that human morals consist of three levels are

a. Pre-conventional Level. At this level, individuals see morals from their own interests. This level is high subjectivity regardless of the considerations and rules agreed upon in society. This stage consists of two stages, namely (1) orientation of punishment and obedience based on the physical risks that occur. Thus, students think by considering whether they behave properly or not so that it results in the punishment they get; (2) the orientation of the instrumental is relative based on a sense of fairness to the rules that have been previously agreed upon. Thus, if it is fair, then other people will behave fairly if the postponement is good.

b. Conventional Level. This level is based on the relationship between the individual and society. Fostering awareness in students to act in accordance with the norms and rules prevailing in society. Therefore, the problem is not only based on a sense of justice but on the rules that apply in society. Continuation of the human moral stage above is (3) interpersonal harmony.

c. Postconventional Level. This level is different from the two previous levels because at this level it is based on awareness of the value of each individual. At this level, it consists of two stages, namely (1) the stage of social contact based on the truth prevailing in society. In other words, individual consciousness acts according to social principles in society; (2) the stage of universal ethical principles is based on universal principles. With the intention of recognizing social contracts based on human obligations.

3. Value clarification techniques. Techniques used to help students can be considered good in finding solutions to the problems at hand. Value clarification techniques aim to (a) measure the level of students\&\#39; awareness of a value; (b) fostering students' awareness of the values they have for a better direction; (c) cultivate a special value that can be accepted by students so that the intended value can be possessed; (d) forming students to be able to make decisions about problems faced in social life.

4. Living Values Education (LVE). One method that can be implemented in fostering character education for students is the Educational Staff Institution (LPTK), namely living values education from UNESCO. LVE focuses on integrity, developing individual potential, positive values for each individual in the process of Education, home, and society. The four objectives of the LVE stated by Tilman (2004) are as follows. (a) reflect on differences in values as the implementation of values associated with the community and the world; (b) motivation and responsibility towards a positive person; (c) fostering personal value by developing practical methods: (d) encouraging teachers and parents to work together in realizing self-integrity with respect and trust.

a) Learning methods are applied by involving student participation which can increase student motivation

b) Creating a conducive learning environment to provide a sense of security and comfort to students

c) Providing comprehensive character education

d) Applying teaching methods to every potential that the child has

\section{Character education in Malaysia}

Character education in Malaysia is different from Indonesia. Character education in Malaysia is different from Indonesia. This is because character education in Malaysia classifies character education into 2 parts, namely Islamic religious education for Muslim students and non-character education for 
non-Muslim students. This character education is given to the young generation of Malaysia since formal school began, the first thought came from England (Rahimah. 1998).

This character education is part of the elementary school level curriculum which originates from the 1996 Law. In the 1996 Law, it contains the philosophy of national education which is integrated with individual personality to create a balanced human being, physically, emotionally, spiritually, intellectually, and socially based. by trust and obedience to god. In this case, human beings who are knowledgeable, competent, are responsible for targeting the welfare of society. Furthermore, the philosophy of education was strengthened by the cabinet report in 1979 (Rahimah. 1998; Vishalache, 2009). The report contains a new curriculum in 1983, for secondary schools starting six years by implementing the integrated high school curriculum. Character education begins in the first year of elementary and middle school students. The following year the curriculum development center at the Malaysian Ministry of Teaching developed the content of the Character Education curriculum by realizing values in society.

In its journey, character education focuses on the spiritual, human, and social aspects of a pluralistic society which transforms into a unity of main values called pure values. Pure values are defined in 16 points, namely kindness, independence, courtesy, respect, love, justice, freedom, courage, cleanliness, honesty, diligence, cooperation, simplicity, gratitude, rationality, and mutual cooperation (Chew. 2010). These sixteen points are related to the behavior of their daily lives so that they can be understood and instilled in students. Character education is carried out through school interactions to apply pure values in everyday life. Character education is carried out in two aspects, namely in writing and in practice.

In its journey, character education focuses on the spiritual, human, and social aspects of a pluralistic society which transforms into a unity of main values called pure values. Pure values are defined in 16 points, namely kindness, independence, courtesy, respect, love, justice, freedom, courage, cleanliness, honesty, diligence, cooperation, simplicity, gratitude, rationality, and mutual cooperation (Chew. 2010). These sixteen points are related to the behavior of their daily lives so that they can be understood and instilled in students. Character education is carried out through school interactions to apply pure values in everyday life. Character education is carried out in two aspects, namely in writing and in practice.

Next, the sixteen points of pure value are integrated with other subjects so that students have a critical and independent footing by obtaining character education that does not conflict with beliefs (Rahimah, 1998). Barriers that teachers find during character education are implemented, for example, funds for activities outside of school, teachers who are less competent in their fields. This results in the ineffective quality of character education (Zarin. 2010). The character education provided is dynamic in order to clarify the values and cognitive development of children (Lickona, 2006). The results of Banks (1993) show that there are five books describing pure values to describe these values encountered outside of school. In fact, the books that are served show more boys than children feeders. These findings indicate that the research subjects are the majority of boys, so there is a gender gap that has an impact on character education, especially girls. Another finding from Banks (1993) that the dominance of Malay ethnicity is used as an illustration in a book so that other ethnicities feel discriminated against. In fact, the results of Banks (1993) research show a moral dilemma so that character education cannot be properly distributed based on cultural and religious tolerance. Other findings also appear that nonverbal messages provide strong messages for students.

\section{Malaysia education structure}

In the education system in Malaysia, Malay and English are used. Low schools are classified into two groups, namely schools of nationality and schools of national types. The two schools have fundamental differences, namely the language of instruction used in the Malay language at the national school and the mandarin language used in the national type school. The Education System adapts the English model that focuses on understanding and analysis. The Islamic-based education model in Malaysia consists of 3 parts, are

a. Teaching based on the psychological point of view of the child. Preschool education has changed the attitudes and behavior of children. Does not differentiate the gender of giving in 
cultivating the values of manners, tolerance, breastfeeding, and being able to show cooperation. not only provide value inculcation to children, but to parents with education from the family. Education from this family can shape the role of each child. Improving the quality of education through the training system for teachers to be able to increase competence in the world of Islamic education

b. Not only provide value inculcation to children, but to parents with education from the family. Education from this family can shape the role of each child

c. Improving the quality of education through the training system for teachers to be able to increase competence in the world of Islamic education

Here are three successes of Malaysian education compared to Indonesia, are

1) Willing to learn from other more developed countries

2) Willing to allocate an adequate amount of education budget

3) Making a systematic long-term planning

\section{Education management}

Availability of facilities and infrastructure and books in a complete library so that students can learn very well. According to Al Kattani (2009), there are a number of factors that cause Malaysia to be attractive, namely:

a. Adequate library facilities with various languages, such as Arabic, English, and representative Malay.

b. Financial assistance to students who are completing a thesis and dissertation

c. Learning using ICT can facilitate the administrative process and teaching and learning activities

d. Relatively cheap tuition fees with adequate facilities

e. Procurement of national and international seminars conducted by Malaysian universities

Table 1. The comparison of Indonesian and Malaysian education

\begin{tabular}{|c|c|c|c|}
\hline \multirow[t]{2}{*}{ No } & \multirow{2}{*}{$\begin{array}{l}\text { Aspects } \\
\text { compared }\end{array}$} & \multicolumn{2}{|c|}{ Comparative Education } \\
\hline & & Indonesia & Malaysia \\
\hline 1 & curriculum & KTSP & Malaysia National Curriculum \\
\hline 2 & $\begin{array}{l}\text { Educational } \\
\text { System } \\
\text { Institutional } \\
\text { aspects and } \\
\text { the period of } \\
\text { learning }\end{array}$ & $\begin{array}{ll}\text { Playgroup } & : 1 \text { year } \\
\text { Elementry } & : 6 \text { year } \\
\text { Junior } & : 3 \text { year } \\
\text { Senior } & : 3 \text { year } \\
\text { Collage } & : 4 \text { year }\end{array}$ & $\begin{array}{lc}\text { Pra School } & : 2 \text { year } \\
\text { Low Education } & : 6 \text { year } \\
\text { Middle Education } & : 3 \text { year } \\
\text { Collage } & : 4 \text { year }\end{array}$ \\
\hline 3 & $\begin{array}{l}\text { Learning } \\
\text { assessment } \\
\text { system }\end{array}$ & Danem & British \\
\hline 4 & $\begin{array}{l}\text { School } \\
\text { identity }\end{array}$ & $\begin{array}{l}\text { Using numbers (student } \\
\text { identification numbers) as } \\
\text { identification numbers on student } \\
\text { cards }\end{array}$ & $\begin{array}{l}\text { Use the Student Name as an } \\
\text { identification number on the student } \\
\text { card }\end{array}$ \\
\hline
\end{tabular}




\begin{tabular}{|c|c|c|c|}
\hline 5 & $\begin{array}{l}\text { Educational } \\
\text { goals }\end{array}$ & $\begin{array}{l}\text { Educate the life of the nation and } \\
\text { develop Indonesian people as a } \\
\text { whole, namely people who } \\
\text { believe and have faith in God } \\
\text { Almighty and have noble } \\
\text { character, knowledge and skills, } \\
\text { physical and spiritual health, a } \\
\text { solid personality, and a sense of } \\
\text { social and national } \\
\text { responsibility. }\end{array}$ & $\begin{array}{l}\text { To realize a learning system that meets } \\
\text { the needs of the state and promotes } \\
\text { cultural, social, economic, and political } \\
\text { development. }\end{array}$ \\
\hline 6 & $\begin{array}{l}\text { Academic } \\
\text { year }\end{array}$ & July to June & July to June \\
\hline 7 & $\begin{array}{l}\text { Educational } \\
\text { budget }\end{array}$ & $\begin{array}{l}\text { Only get } 20 \% \text { of the government } \\
\text { budget. }\end{array}$ & Receive $25 \%$ of the government budget \\
\hline 8 & $\begin{array}{l}\text { Education } \\
\text { system }\end{array}$ & Decentralization & Decentralization \\
\hline
\end{tabular}

\section{Conclusion}

Based on the results of this study, it shows that Indonesia's education policy is based on the philosophy of Pancasila and the 1945 Constitution, while Malaysia's education policy still adapts to education from its colony, England. When compared from the four policy components of Indonesia and Malaysia, namely the objectives of character education, character education strategy, education structure, and education management. It can be said that Malaysia tends to be more advanced than Indonesia because the community gets free education in Malaysia, and much other assistance is obtained by the community from the aspect of education.

\section{Limitations and study forward}

Four components are studied in Indonesian and Malaysian policies, namely character education goals, character education strategies, education structures, and education management. There are still many other aspects related to education policy that has not been discussed and can be used as recommendations for further research.

\section{References}

Abdi, I., M. (2018). The Implementation of Character Education in Kalimantan, Indonesia: Multi Site Studies, Dinamka Ilmu, 18 (2), 305-321.

Anggraini, P., and Kusniarti, T. (2017). Character and Local Wisdom Based Instructional Model of Bahasa Indonesia in Vocational High Schools. Journal of Education and Practice, 8 (5), 2329.

Amabile, T. M., \& Conti, R. (1999). Changes in The Work Environment for Creativity During Downsizing. Academy of Management Journal, 42(6), 630-640.

Aunillah, N., I. (2011). Panduan Menerapkan Pendidikan Karakter di Sekolah. Yogyakarta: Laksana.

Banks, J. (1993). Multicultural education: Historical Development, Dimensions, and Practice, American Educational Research Association, 19 (1993), 3-9

Chew F, P. (2010). Penerapan Nilai-Nilai Murni Menerusi KOMSAS dalam Sistem Pendidikan Malaysia. Sosiohumanika. 3 (1), 123-142.

Collin, C, T. (2002). PR: Pedoman Praktis Untuk PR. Jakarta: PT. Bumi Aksara 
Departemen Pendidikan Nasional. 2014. Kamus Besar Bahasa Indonesia. Jakarta : Gramedia Pustaka Utama

Drucker, F. (1990). Leading for Innovation. New York

Emzir. (2010). Metodologi Penelitian Pendidikan:Kuantitatif dan Kualitatif. Jakarta: Rajawali Pers.

Hanh, D, N., Loan, Q, V., and Viet, M, N. (2020). Quality Framework of Higher Education in Vietnam, Malaysia, and Nigeria, Higher Education Studies, 10 (2), 133-144.

Istianingsih. (2016). Character Education of The Most Develope Countries ASEAN. Journal of Education and E Learning Research, 3 (1), 32-37.

Kim, K., Harris, C, J., and Pham, L (2018). How Character Education Impact Teachers. International Journal of Multidiciplinary Perspective in Higher Education, 3 (1), 45-67

King, N., and Neil A. (1995). Innovation and Change Organization. Routledge London and New York

Langgulung, H. (1992). Asas-Asas Pendidikan Islam. Jakarta: Pustaka Al Husna

Lickona, T. (1993). The Return of Character Education. Educational Leardership. 51 (3), 6-11.

Mansikana, A., and Anggraeni, W, C. (2018). Pendidikan Karakter dan Mutu Pendidikan Indonesia, Seminar Nasional Pendidikan III, 102-110. Surakarta: Universitas Muhammadiyah Surakarta.

Marini A., Safiti, D., dan Muda, I. (2018). Managing School Based on Character Building in The Context of Religius School Culture, Journal of Social Studies Education Research, 9 (4), 274294.

Maunah, B. (2015). Implementasi Pendidikan Karakter dalam Pembentukan Kepribadian Holistik Siswa, Jurnal Pendidikan Karakter, V (1), 90-101.

Milal, D., Rohmah, Z., Kusumajanti, W. (2020). Integrating Character Education in The English Teaching at Islamic Junior High Schools In Indonesia. TEFLIN Journal, 31 (2), 88-107.

Nurainda dan Aulia, N, R. (2009). Pendidikan Karakter untuk Guru. Ciputat: Islamic Research Publishing.

Oldham, G. R., \& Cummings, A. (1996). Employee creativity: Personal and contextual factors at work. Academy of Management Journal, 39 (3), 607-634.

Plomp. T. (1997). Educational and Training System Design. Enschede, Netherlands: Twente University

Rahimah, H, A. (1998). Educationa Development and Reformation in Malaysia: Past, Present, and Future. Jounal of Educational Administration, 36 (5), 462-475.

Rogers, E., and Shoemaker, F. (1987). Memasyarakatkan Ide-Ide Baru, Terjemahan Abdillah Hanafi. Surabaya: Usaha Nasional.

Rosmiati, Mahmud, A., dan Talib, S. (2016). The Effectiveness of Learning Model of Basic Education with Character Based at Universitas Muslim Indonesia. International Journal of Environtment and Science Education, 11 (12), 5633-5643.

Saidek, R, A., Islami, R., and Abduludin. (2016). Character Issues: Reality Character Problems and Solutions through Education in Indonesia, Journal of Education and Practice, 7 (17), 158-165.

Santika, E, W, I. (2020). Pendidikan Karakter pada Pembelajaran Daring. Indonesian Value and Character Education Journal, 3 (1), 8-19

Soedijarto. (2000). Pendidikan Nasional sebagai Wahana Mencerdaskan Kehidupan Berbangsa dan Membangun Peradaban Negara Bangsa. Jakarta: Cinaps

Sokip et al. (2019). Character Buildinase Study in Islamic Society of Muslim Families in Tulungagung, East Java, Indonesia. Journal of Social Studies Education Research, 10 (2), 224-242.

Sukmadinata, et al. (2006). Pengendalian Mutu Pendidikan Sekolah Menegah. Bandung: Aditama

Sulistiyowati, E. (2013). Pendidikan Karakter dalam Pembelajaran Bahasa Indonesia. Edukasia: Jurnal Penelitian Pendidikan Islam. 8 (2), 312-330.

Sumintono et al. (2012). Pendidikan Moral di Malaysia: Tantangan dan Implementasi Pendidikan Karakter

Thambusamy, R., and Elier, A, A. (2013). Shaping the Bamboo from the Shoot: Elementary Level Character Education in Malaysia, Chidhood Education, 369-378. 
Tsai, W. (2001). Knowledge transfer in intra organizational network: Effect of network position absorptive capacity on business unit innovation and performance. Academic of Management Journal, 44, 996-1004. http://doi: 10.2307/3069443

Uno, H. (2006). Profesi Kependidikan. Jakarta: Bumi Aksara

Vishalache, B. (2009). Teaching Moral Education in Secondary Schools Using Real life Dilemmas. Unpublished PhD Thesis at Victoria University of Wellington, New Zealand.

Wijaya et al. (1992). Upaya Pembaharuan dalam Pendidikan dan Pengajaran. Bandung: Remaja Rosdakarya.

Yuliana, D. (2010). Pentingnya Pendidikan Karakter Bangsa guna Merevitalisasi Ketahanan Bangsa. Udayana Mengabdi, 9 (2), 92-100.

Zarin, I. (1990). Masalah Pengajaran Pendidikan Moral KBSM Tingkatan 1: Latihan Ilmiah. Universiti Kebangsaan Malaysia. 